УДК 347.4

DOI https://doi.org/10.32837/pyuv.v1i3(28).332

\author{
T. Я.Puм \\ кандидат юридичних наук, \\ суддя \\ Господарського суду Львівської області
}

\title{
АКТИВИ ПАЙОВОГО ІНВЕСТИЦІЙНОГО ФОНДУ ЯК ВИД ІНВЕСТИЦІЙ У СФЕРІ БУДІВНИЦТВА
}

Український законодавець, маючи на меті запровадити сучасні форми інвестування, постійно удосконалює правове регулювання інститутів спільного інвестування як найбільш перспективних та ефективних форм залучення інвестицій. Пайовий інвестиційний фонд посідає серед них помітне місце. Разом з тим особливості формування активів цього фонду, їх правової природи породили значні труднощі в контексті здійснення та захисту інвесторами їх прав у цьому фонді.

До аналізу поняття пайового інвестиційного фонду зверталися такі науковці, як О.М. Гнатів, Д.Й. Клапатий, Л.В. Машковська, О.А. Слободян, І.Я. Полянська та інші.

Метою цієї статті є з'ясування складу активів пайового інвестиційного фонду, аналіз об'єктів, що входять до складу активів цього фонду.

Здійснення інвестиційної діяльності у формі інвестиційних фондів вперше в Україні було запроваджено у 1994 році Указом Президента України «Про інвестиційні фонди та інвестиційні компанії» від 19 лютого 1994 року [1]. Під спільним інвестуванням у названому Указі визначалася діяльність, яка здійснювалася в інтересах і за рахунок засновників та учасників інвестиційного фонду. Названий Указ передбачав функціонування фонду у формі юридичної особи. Можливим було створення взаємних фондів інвестиційних компаній, які мали статус філій інвестиційних компаній і здійснювали спільне інвестування від iї імені.

На законодавчому рівні функціонування пайових фондів було врегульовано Законом України від 15 березня 2001 року «Про інститути спільного інвестування (пайові та корпоративні інвестиційні фонди)» [2]. Названий акт встановлював правові рамки діяльності пайових фондів. Зокрема, визначив поняття пайового фонду, його структуру, підстави і механізм створення та припинення діяльності.

В Указі Президента України «Про інвестиційні фонди та інвестиційні компанії» було затверджено положення про правовий статус фінансових посередників, які здійснювали діяльність із спільного інвестування. Хоча цим актом установлювалися форми спільного інвестування, правила здійснення інвестиційної діяльності, потрібно враховува- ти, що метою зазначеного підзаконного акту було забезпечення обігу приватизаційних паперів.

Спільне інвестування з використанням інвестиційних фондів та інвестиційних компаній здійснювалося шляхом викупу інвестиційних сертифікатів, які набувалися інвесторами у власність за грошові кошти або в обмін на приватизаційні папери. Пізніше інвестиційні кошти вкладалися в цінні папери інших емітентів.

Встановлення в законодавстві правового статусу інвестиційних фондів та інвестиційних компаній дало змогу уникнути великої кількості власників державних підприємств, що створювало б проблеми під час здійснення управління ними. Названі структури як юридичні особи дали можливість сконцентрувати інвестиційні кошти в руках професійного управителя, який здійснював управління активами інвестиційного фонду. Однак тогочасне законодавство не передбачало засобів контролю за ефективністю використання інвестованих коштів. Це слугувало підставою прийняття нормативних актів, спрямованих на удосконалення механізму спільного інвестування. Зокрема, 26 листопада 1994 року було затверджено Указ Президента «Про заходи щодо забезпечення прав громадян на використання приватизаційних майнових сертифікатів» [3], яким передбачалися розрахунки з учасниками інвестиційних фондів та інвестиційних компаній у разі їх ліквідації та реорганізації.

Законом України «Про інститути спільного інвестування (пайові та корпоративні інвестиційні фонди)» від 15.03.2001 була вказана мета названого акту законодавства - залучення та ефективне розміщення фінансових ресурсів інвесторів. Визначалися види та правовий статус інвестиційних фондів та інвестиційних компаній, вводилося поняття коштів спільного інвестування та пов'язаних осіб, встановлювалися обмеження щодо операцій компаній з управління активами під час здійснення нею управління та обсяги їх відповідальності.

3 прийняттям Закону України «Про цінні папери та фондовий ринок» [4] врегульовано функціонування фондового ринку, у тому числі пайових фондів. Визначено правовий режим інвестиційних сертифікатів компанії з управління активами 
пайового фонду, розмежовано види емісії цінних паперів інститутів спільного інвестування на публічне та приватне розміщення, визначено поняття недобросовісної емісії цінних паперів.

Водночас потреба удосконалення механізму функціонування інвестиційних фондів зумовила прийняття 5 липня 2012 року Закону України «Про інститути спільного інвестування» [5]. Цим законом запроваджено кардинальні зміни в регламентації функціонування пайових фондів. Зокрема, визначено етапи створення пайових фондів, запроваджено бездокументарну форму випуску інвестиційних сертифікатів пайового фонду, удосконалено процедуру нагляду за діяльністю пайового фонду.

Законодавче визначення пайового фонду міститься в ч. 1 ст. 41 Закону України «Про інститути спільного інвестування». Так, пайовий фонд визначається як сукупність активів, що належать учасникам такого фонду на праві спільної часткової власності, перебувають в управлінні компанії з управління активами та обліковуються нею окремо від результатів її господарської діяльності. Це визначення має узагальнюючий характер для функціонування пайових фондів в різних галузях господарської діяльності. Стосовно сфери будівництва вказану вище дефініцію можна брати за основу для визначення правового режиму активів пайового фонду.

В літературі обгрунтовуються різноманітні теорії правової природи пайового фонду. Зокрема, I.В. Венедіктова розглядає пайовий фонд як майновий комплекс [6, с. 157]. Майновий комплекс представляє собою пов'язаний спільною метою зв'язок окремих об'єктів, які є елементами єдиної структури.

Незважаючи на те, що в літературі широко використовується термін майновий комплекс, в ЦК України визначається лише поняття підприємства як єдиного майнового комплексу. А.А. Герц зазначає, що однією з основних ознак майнового комплексу підприємства як об'єкта цивільних правовідносин є цілісність і єдність його елементів [7, с. 8].

Аналіз різноманітних точок зору щодо поняття майнового комплексу як об’єкта правовідносин дозволяє виокремити такі ознаки:

- до складу майнового комплексу належать кілька компонентів з різним правовим режимом, які становлять єдине ціле;

- елементи майнового комплексу використовуються для спільного цільового призначення;

- правовий зв'язок між елементами майнового комплексу;

- функціональний взаємозв'язок елементів майнового комплексу як єдиного цілого.

Пайовий фонд є сукупністю активів, що належать учасникам фонду на праві спільної часткової власності. Під активами розуміється сформована за рахунок коштів спільного інвестування сукупність майна, яка належить на праві спільної часткової власності інвесторам. Аналіз структури пайового фонду свідчить, що його не можна ототожнювати 3 майновим комплексом. Останній становить єдине ціле в розумінні використання в сукупності всіх елементів для певної мети. Активи пайового фонду можуть використовуватися шляхом їх вкладення в різноманітні об'єкти інвестиційної діяльності.

Основою формування пайового фонду є матеріалізовані цінності, переважно грошові кошти, тоді як до складу майнового комплексу, наприклад підприємства, входять також нематеріальні активи у вигляді гудвілу, прав інтелектуальної власності тощо.

Значення має також правовий режим майна. Пайовий фонд формується за рахунок інвестиційних вкладів учасників, внаслідок чого їх право приватної власності на інвестицію трансформується у правовий режим спільної часткової власності. Майновий комплекс як цілісний об'єкт, що об'єднує структурні елементи з різною правовою природою, характеризується як єдине ціле в цивільному обороті.

Так, до складу майнового комплексу підприємства як об’єкта цивільних правовідносин входять права інтелектуальної власності, права користування ресурсами природного середовища (земельними ділянками, надрами тощо), гудвіл, який включає ділову репутацію. Податковий кодекс України окремо виділяє нематеріальні активи як складову частину майнового комплексу підприємства, до яких належать перелічені вище об'єкти.

Поряд з нематеріальними активами до складу майнового комплексу входять матеріальні складники. Адже майнову основу будь-якої господарської чи інвестиційної діяльності складають матеріальні активи: грошові кошти, речі та пов'язані 3 ними майнові права. Сукупність матеріальних та нематеріальних активів складають цілісний об’єкт правовідносин. Власне, термін «комплекс» походить від латинського слова “complex" - зв'язок, поєднання, сполучення предметів чи явищ, які становлять єдине ціле.

Ст. 48 Закону України «Про інститути спільного інвестування» передбачає, що до складу активів венчурного фонду можуть входити боргові зобов'язання. Такі зобов'язання можуть бути оформлені векселями, заставними, договорами відступлення прав вимоги, позики та в інший спосіб, не заборонений законодавством. Активи венчурного фонду можуть повністю складатися 3 коштів, нерухомості, корпоративних прав, прав вимоги та цінних паперів, що не допущені до торгів на фондовій біржі. При цьому, згідно з п. 3 розділу 5 Положення про склад та структуру активів спільного інвестування, затвердженого рішенням 
Національної комісії з цінних паперів та фондового ринку від 10 вересня 2013 року, активи венчурного фонду можуть повністю складатися з коштів, нерухомості, корпоративних паперів, що не допущені до торгів на фондовій біржі.

Права вимоги можуть бути залучені винятково до складу активів венчурного фонду та лише за кредитними договорами. Залучення компанією 3 управління активами до складу активів венчурного фонду прав вимоги за кредитним договором здійснюється шляхом укладення з банківською установою договору відступлення права вимоги. Предметом договору права відступлення права вимоги може бути право вимоги за кредитним договором, оцінка вартості якого проведена банківською установою з урахуванням ризиків невиконання боржником своїх зобов'язань. Віднесення боргових зобов'язань до активів інституту спільного інвестування може привести до порушення прав та інтересів інвесторів та третіх осіб.

Прикладом є справа № 369/2426/17 [8], яка розглядалася Києво-Святошинським районним судом Київської області 20 квітня 2017 року. Суть спору полягала в наступному: на підставі договору купівлі-продажу майнових прав від 23.09.2016 між ТОВ «Бориспільміськбуд» в особі забудовника та ТОВ «Компанія з управління активами та адміністрування пенсійних фондів «Даліз-Фінанс» , що діяла від імені та в інтересах АТ «ЗНВКІФ «Княгиня Ярославна»» в особі покупця, останній придбав майнові права на квартиру № 16 в будинку № 2 , четвертий поверх в об’єкті будівництва - житловий комплекс по вулиці Поліській в Дарницькому районі міста Києва.

Надалі на підставі договору від 02.12.2016 про відступлення прав та обов'язків між ТОВ «Бориспільміськбуд» в особі забудовника ТОВ «Компанія з управління активами та адміністрування пенсійних фондів «Даліз-Фінанс»», що діє від імені та в інтересах АТ «ЗНВКІФ «Княгиня Ярославна»" в особі первісного покупця та Особа_1 в особі нового покупця, АТ «ЗНВКІФ «Княгиня Ярославна»" оплатно здійснила відступлення прав та обов'язків за договором купівлі-продажу майнових прав від 23.09.2016 замість АТ «ЗНВКІФ «Княгиня Ярославна»».

Серед іншого позивач - Особа_1, зазначив, що в силу того, що АТ «ЗНВКІФ «Княгиня Ярославна»» є одним 3 видів інституту спільного інвестування у вигляді закритого недиверсифікованого венчурного корпоративного інвестиційного фонду, існують певні обмеження стосовно можливості операцій з активами такого товариства у вигляді права вимоги, які є предметом оскаржуваних договорів. Позивач вважав, що на підставі укладення спірних договорів АТ «ЗНВКІФ «Княгиня Ярославна»» було залучено до складу своїх активів право вимоги, проте це прямо суперечить при- писам розділу $\mathrm{V}$ вищеназваного Положення про склад та структуру інституту спільного інвестування, яким передбачена можливість залучати до складу активів АТ «ЗНВКІФ «Княгиня Ярославна»" права вимоги винятково за кредитними договорами, укладеними з банківською установою, а не за спірними договорами. Крім того, позивач наголошував, що на підставі укладених спірних договорів АТ «ЗНВКІФ «Княгиня Ярославна»» було залучено до складу своїх активів право вимоги, проте наведене прямо суперечить приписам розділу V вищеназваного Положення, оскільки в цьому випадку мають місце всі ознаки договору факторингу, до якого застосовуються положення ст. 1077 ЦК України.

Відповідачі - ТОВ «Бориспільміськбуд» та АТ «ЗНВКІФ «Княгиня Ярославна»», заперечуючи проти позову, вказували, що предметом договору від 23.09.2016 є винятково майнові права на квартиру № 16 в будинку № 2 в об'єкті будівництва житловий комплекс по вулиці Поліській в Дарницькому районі міста Києва, який на час укладення договору перебував у процесі будівництва і не введений в експлуатацію. 3 огляду на це відповідачі стверджували, що аналізований договір не $\epsilon$ відступленням права вимоги на нерухоме майно, а отже, на нього не поширюються положення ст. 657 ЦК України.

Відповідно, на думку відповідачів, оскільки АТ «ЗНВКІФ «Княгиня Ярославна»» є одним 3 видів інституту спільного інвестування у вигляді закритого недиверсифікованого венчурного корпоративного інвестиційного фонду, на нього розповсюджують свою дію вимоги Положення про склад та структуру інституту спільного інвестування, що затверджене рішенням Національної комісії з цінних паперів та фондового ринку від 10.09.2013, зареєстрованого в Міністерстві юстиції України 01.10.2013 № 1682/24221.

Проте на підставі укладених договорів АТ «ЗНВКІФ «Княгиня Ярославна»» було залучено до складу своїх активів не право вимоги, як це зазначено позивачем, а боргове зобов'язання та кошти, що цілком відповідає як вимогам ч. 4 ст. 48 Закону України «Про інститути спільного інвестування», так і приписам п. 3 розділу $\mathrm{V}$ названого вище Положення, які передбачають, що до складу активів венчурного фонду можуть входити боргові зобов'язання і кошти.

Крім того, відповідачі зазначали, що предметом договору від 02.12.2016 не є передача або зобов'язання передати грошові кошти в розпорядження другої сторони за плату (грошові вимоги до третьої особи) і вони не є фінансовими установами, а отже, вищезгаданий договір не є договором факторингу в розумінні ст. 1077 ЦК України.

Аналіз коментованої справи з інвестування будівництва дає можливість дійти наступних 
висновків. Майновими визнаються будь-які права, пов'язані з майном, відмінні від права власності, але є складовою частиною змісту права власності. В нашому випадку суд дійшов висновку, що спірний договір не може бути договором купівлі-продажу нерухомого майна, оскільки відповідне майно на момент укладення договору ще не існувало. Тому майнові права на нерухомість об'єкт інвестування, не існують і їх не можна вважати речовими правами на чуже майно.

3 огляду на те, що об'єкт перебував у процесі будівництва і не був введений в експлуатацію, суд вважав, що в такому разі мало місце передання до активів АТ «ЗНВКІФ «Княгиня Ярославна»» боргового зобов'язання у вигляді грошової суми. При цьому суд посилався на ч. 4 ст. 48 Закону України «Про інститути спільного інвестування», згідно 3 якою до складу активів венчурного фонду можуть входити боргові зобов'язання.

Законодавець часто використовує термін «борг», «боргове зобов'язання», «право вимоги», не розкриваючи їх змісту в контексті характеристики поняття майнового комплексу або зобов'язальних відносин в інвестиційній сфері.

Кредитор має право вимоги до боржника, яке можна трактувати як відкладену можливість отримати матеріальну вигоду в майбутньому. Але таку можливість не можна ототожнювати 3 реальними майновими активами. Адже право вимоги кредитора може бути не задоволено зі сторони боржника з об'єктивних чи суб'єктивних обставин.

У таких випадках йдеться про невиконання або неналежне виконання своїх зобов'язань боржником. Відповідно, кредитор не отримує матеріального еквіваленту, який становить зміст права вимоги. Таким чином, право вимоги «зависає», внаслідок чого не відбувається збільшення активів уповноваженої особи як складової частини iï майна. Наведене повністю стосується активів інвестиційних фондів. Потенційна можливість ïх збільшення за рахунок боргових зобов'язань може не відбутися внаслідок невиконання своїх зобов'язань боржником.

Отже, аналіз структури активів пайового інвестиційного фонду дозволяе зробити висновок, що він відрізняється за своєю правової природою від майнового комплексу підприємства. Зокрема:

1) майновий комплекс становить єдине ціле в розумінні використання в сукупності всіх елементів для певної мети;

2) основою формування пайового фонду є матеріалізовані цінності, переважно грошові кошти, тоді як до складу майнового комплексу входять також нематеріальні активи у вигляді гудвілу, який включає ділову репутацію, прав інтелектуальної власності, прав користування ресурсами природного середовища тощо.
На наш погляд, помилковим є закріплення в ч. 4 ст. 48 Закону України «Про інститути спільного інвестування» положення про те, що до складу активів венчурного фонду можуть входити боргові зобов'язання. Так, можливість у майбутньому отримати матеріальну вигоду не можна ототожнювати з реальними майновими активами. Адже право вимоги кредитора може бути не задоволено зі сторони боржника з об'єктивних чи суб'єктивних причин.

\section{Jimepamypa}

1. Про інвестиційні фонди та інвестиційні компанії: Указ Президента України від 19.02.1994 p. URL: https://zakon.rada.gov.ua/laws/show/55/94.

2. Про інститути спільного інвестування (пайові та корпоративні інвестиційні фонди): Закон України від 15.03.2001. Відомості Верховної Ради України. 2001. № 21. ст. 103.

3. Про заходи щодо забезпечення прав громадян на використання приватизаційних майнових сертифікатів: Указ Президента України від 26.11.1994. URL: https://zakon.rada.gov.ua/laws/show/699/94.

4. Про цінні папери та фондовий ринок: Закон України від 23.02.2006. Відомості Верховної Ради України. 2006. № 31. ст. 268.

5. Про інститути спільного інвестування: Закон України від 05.07.2012.URL:https://zakon.rada.gov.ua/ laws/show/5080-17.

6. Венедіктова I.В. Договір довірчого управління майном в Україні. Харків : Консум, 2004. с. 157.

7. Герц А.А. Іпотека підприємства як єдиного майнового комплексу : автореф. дис. ... канд. юрид. наук : 12.00.03. Львів; 2006. 17 с.

8. Рішення Києво-Святошинського районного суду Київської області у справі № 369/2426/17 від 20.04.2017. URL: http://www.reyestr.court.gov.ua/ Review/66235137.

\section{Анотація}

Рим Т. Я. Активи пайового інвестиційного фонду як вид інвестицій у сфері будівництва. - Стаття.

$\mathrm{y}$ статті проведено аналіз складу активів пайового інвестиційного фонду як різновиду інвестицій. Зазначено, що можливість здійснення інвестиційної діяльності у формі інвестиційних фондів вперше на законодавчому рівні було закріплено в 1994 році. Наведено основні джерела правового регулювання створення та діяльності пайових інвестиційних фондів.

Проаналізовано правову природу пайового інвестиційного фонду в контексті поняття майнового комплексу як об’єкта цивільних правовідносин. Зроблено висновок, що пайовий інвестиційний фонд не можна ототожнювати з майновим комплексом. Адже останній становить єдине ціле в розумінні використання в сукупності всіх елементів для певної мети. Активи пайового фонду можуть використовуватися шляхом їх вкладення в різноманітні об'єкти інвестиційної діяльності.

Основою формування пайового фонду є матеріалізовані цінності, переважно грошові кошти, тоді як до складу майнового комплексу входять також нематеріальні активи у вигляді гудвілу, який включає ділову репутацію, прав інтелектуальної власності, прав користування ресурсами природного середовища тощо.

Окрему увагу в статті присвячено борговим зобов'язанням, які входять до складу активів венчурного фонду. Зокрема, такий вид активу пайового фонду може 
призвести до порушення прав та інтересів інвесторів та третіх осіб. Автором наводиться приклад із судової практики, який наочно демонструє ризикованість віднесення до складу активів пайового фонду боргових зобов'язань.

Обгрунтовано, що кредитор має право вимоги до боржника, яке можна трактувати як відкладену можливість отримати матеріальну вигоду в майбутньому. Але таку можливість не можна ототожнювати з реальними майновими активами. Адже право вимоги кредитора може бути не задоволено зі сторони боржника з об'єктивних чи суб'єктивних обставин.

Робиться висновок, що боргові зобов'язання не можна відносити до активів інституту спільного інвестування у формі інвестиційного фонду.

Ключові слова: інвестиції, інститут спільного інвестування, пайовий інвестиційний фонд, активи пайового інвестиційного фонду.

\section{Summary}

Rym T. Ya. Share investment fund assets as a type of investments in the construction sphere. - Article.

The article analyzes the composition of share investment fund assets as the type of investments. It was noted that the possibility of investment activity in the form of investment funds was firstly fixed at the legislative level in 1994. The main sources of legal regulation of creation and activity of share investment funds are given.

The legal nature of the share investment fund is analyzed in the context of analyzing the concept of property complex. It is concluded that a share investment fund cannot be equated with a property complex, since the latter is a whole in understanding the use of all the elements for a specific purpose. Share investment fund assets can be used by investing them in various investment activities.

The basis for the formation of a unit fund is materialized values, mainly money, while the property complex also includes intangible assets in the form of goodwill, which includes business reputation, intellectual property rights, rights to use natural resources and so on.

Particular attention in the article is devoted to debt obligations which are part of the assets of the venture fund. In particular, this type of share investment fund asset may lead to a violation of the rights and interests of investors and third parties. The author gives an example from the case law, which clearly demonstrates the riskiness of the assignment of debt obligations to the assets of a share investment fund.

It is grounded that the creditor has the right to claim against the debtor, which can be interpreted as a deferred opportunity to obtain material gain in the future. But such an opportunity cannot be equated with real property assets. After all, the right of claim of the creditor may not be satisfied by the debtor on objective or subjective circumstances.

It is concluded that debt obligations cannot be attributed to assets of a joint investment institutions in the form of an investment fund.

Key words: investments, joint investment institute, share investment fund, assets of share investment fund. 